\title{
Ingkar Hadis di Indonesia dan Mayasia (Studi Komparatif Pemikiran Hadis Nazwar Syamsu dan Kassim Ahmad)
}

\author{
Nurfajriyani \\ Institut Agama Islam Negeri Ambon \\ Email: nurfairiyani@iainambon.ac.id
}

\begin{abstract}
This article is entitled "Ingkar Hadith in Indonesia and Malaysia: A Critical Study of the Thought of Nazwar Syamsu and Kassim Ahmad". The understanding of the rejection of the Prophet's hadith as a source of Islamic law after the Al-Qur'an also influenced the thinking of intellectual figures in Indonesia such as Nazwar Syamsu and Kassim Ahmad in Malaysia. This research then focuses on the following three issues: first, how is the history of the origins of the development of Ingkar Sunnah in Indonesia and Malaysia ?; second, what is the thought of the hadith of the Sunnah renegades, namely Nazwar Syamsu and Kassim Ahmad ?; third, how are the similarities and differences as well as the implications of their thinking? This research is a qualitative research based on library research (library research). In analyzing the data that has been collected, the researcher uses descriptive, analytical, and comparative methods. The results of this study are, first, Ingkar Sunnah in Indonesia appeared secretly in 1978. Meanwhile in Malaysia the anti-hadith movement only emerged in 1985 which was pioneered by Kassim Ahmad; Both the thoughts of Nazwar and Kassim both reject hadith because hadith is a lie not only from the Prophet SAW and is a factor for the decline of Muslims; The three comparisons of the thoughts of Nazwar and Kassim lie in their influence on orientalists and the book readings of previous hadith deniers.
\end{abstract}

Keywords: Ingkar Hadith, Nazwar Syamsu, Kasim Ahmad.

Abstrak: Artikel ini ini berjudul "Ingkar Hadis di Indonesia dan Malaysia: Studi Kritis Pemikiran Hadis Nazwar Syamsu dan Kassim Ahmad". Pemahaman penolakan terhadap hadis Nabi sebagai sumber hukum Islam setelah Al-Qur'an turut mempengaruhi pemikiran para tokoh intelektual di Indonesia seperti Nazwar Syamsu dan Kassim Ahmad di Malaysia. Penelitian ini kemudian difokuskan pada tiga persoalan berikut: pertama, bagaimana sejarah asal-usul berkembangnya Ingkar Sunnah di Indonesia dan Malaysia?; kedua, bagaimana pemikiran hadis dari tokoh-tokoh ingkar Sunnah yakni Nazwar Syamsu dan Kassim Ahmad?; ketiga, bagaimana persamaan dan perbedaan serta implikasi dari pemikiran keduanya?. Penelitian ini merupakan penelitian kualitatif yang didasarkan pada studi kepustakaan (library reseach). Dalam menganalisis data yang telah terkumpul peneliti menggunakan metode deskriptif, analisis, dan metode komparatif. Hasil penelitian ini adalah, pertama, Ingkar Sunnah di Indonesia telah muncul secara diam-diam pada tahun 1978. Sedangkan di Malaysia gerakan anti hadis baru muncul pada tahun 1985 yang dipelopori oleh Kassim Ahmad; Kedua pemikiran dari Nazwar dan Kassim sama-sama menolak hadis karena hadis merupakan suatu kebohongan semata bukan berasal dari Nabi SAW dan merupakan faktor kemundurannya umat Islam; Ketiga perbandingan dari pemikiran Nazwar dan Kassim terletak pada faktor keterpengaruhan mereka terhadap orientalis serta bacaan-bacaan buku dari para pengingkar hadis sebelumnya.

Kata Kunci: Ingkar Hadis, Nazwar Syamsu, Kassim Ahmad. 


\section{PENDAHULUAN}

Adanya Al-Qur'an dan hadis merupakan pondasi dan dasar pokok ajaran agama Islam. Al-Qur'an yang memiliki kualitas absolute (qat'i>) yang secara level tidak bisa dibandingkan dengan hadis yang bersifat zanni>, terlebih jika melihat asal (sumber) dari keduanya. Pernyataan tersebut sudah menjadi rahasia umum bagi umat muslim bahkan non muslim sendiri. Terlepas dari eksistensinya maupun tingkatannya, Al-Qur'an tidak bisa dipisahkan dari Hadis, keduanya saling melengkapi dan menyempurnakan dalam mengurai ajaran agama Islam. Kenyataan yang mulai digoyahkan dan dikritisi oleh beberapa pemikir yang cenderung dan menginginkan kembali pada AlQur'an an sich. Suatu hal yang dapat dimaklumi mengingat keberadaan hadis baik dari proses tadwin, penyampaian, bahkan kualitas hadis masih menyimpan dan memiliki problem yang kompleks. ${ }^{1}$

1 Pengumpulan hadis dilakukan jauh setelah nabi wafat, mengingat sebelumnya
Dalam sejarah umat Islam hanya sekelompok kecil dari umat Islam yang menolak hadis Nabi Sebagai sumber ajaran Islam. Mereka ini dikenal dengan kelompok Inkar alSunnah atau Inkar al-Hadis| dengan berbagai latar belakang dan motifnya dalam batasan tertentu telah menjadi masalah tersendiri sejak zaman klasik hingga masa modern, ${ }^{2}$ baik dalam kaitannya pemahaman ajaran Islam keseluruhan maupun dalam kaitannya dengan posisi Hadis sebagai salah satu sumber ajaran Islam. Secara empirik, muncul dan dilarang menulis atau mencatat hadis. Tentang keadilan sahabat (dengan jargon kull sahabat 'udul) yang memiliki otoritas menyampaikan hadis masih menjadi perdebatan hingga sekarang. Penilain atas riwayat bi al-ma'na, secara tidak langsung dapat membuat keraguan, yang dimungkinkan adanya qaul-qaul sahabat, tabi'in masuk dan bercampur dalam hadis. Hal ini merupalan problem yang masih melekat dalam kajian hadis yang hingga sekarang masih dikaji.

2 Penggunaan periode klasik dalam kajian ini merujuk pada periodisasi sejarah perkembangan Islam yang dikemukakan oleh Harun Nasution. Beliau membagi menjadi tiga periode,yaitu periode klasik (650-1250), periode pertengahan (1250-1800), dan periode modern (1800-sampai sekarang). Lihat, Harun Nasution, Islam Ditinjau dari Berbagai Aspeknya, jilid I, Cet V (Jakarta: UI Press, 1989), 56-89. 
berkembangnya ingkar hadis tersebut telah menjadi salah satu faktor keresahan masyarakat muslim, khususnya di Indonesia dan Malaysia sebagai negara penduduk muslim terbanyak.

\section{PEMBAHASAN}

1. Sejarah kemunculan Ingkar Hadis di Indonesia dan Malaysia

Tidak diketahui persis sejak kapan Ingkar Hadis mulai berkembang di Indonesia dan siapa yang mula-mula menyebarkannya, Gerakan Ingkar Hadis di Indonesia menjadi target para pengingkar hadis setelah Mesir, karena Indonesia berpenduduk mayoritas Islam terbanyak di seluruh dunia Islam. Hal ini dapat dilihat sekitar tahun 1980-an paham pemikiran modern Ingkar Hadis Indonesia bergerak di beberapa tempat dan pada tahun 1983-1985 mencapai puncaknya sehingga menghebohkan masyarakat Islam dan memenuhi halaman berbagai harian koran dan majalah. Pusat pergerakan mereka di Jakarta yang mendominasi jumlah pembawanya yang mayoritas, kemudian di Bogor Jawa Barat, Tegal Jawa Tengah dan Padang Sumatera Barat. ${ }^{3}$

Terbitnya beberapa buku yang bercorak Ingkar Hadis dan munculnya beberapa tulisan yang mengecam para pengingkar hadis tersebut hingga keluarnya fatwa Majelis Ulama Indonesia (MUI) pada tanggal 27 Juni 1983 tentang Kesesatan Ingkar Sunnah ${ }^{4}$ serta Surat keputusan Kejaksaan Agung 5 yang melarang paham tersebut.

Nazwar Syamsu termasuk salah satu tokoh pengingkar hadis dari Indonesia beliau di golongkan

3 Abdul Majid Khon, Pemikiran Modern dalam Sunnah, (Jakarta: Kencana, 2011), 100101.

4 Fatwa tersebut dikeluarkan oleh Majelis Ulama Indonesia tanggal 27 Juni 1983. Lihat, Majelis Ulama Indonesia Indonesia, Himpunan Fatwa MUI, (Jakarta: 2003), 108-109.

5 Kejaksaan Agung RI. telah mengeluarkan tiga Surat Keputusan yang isinya melarang penyebaran paham/ajaran Ingkar Sunnah, yaitu Kep.-169/J.A/9/1983 tanggal 30 September 1983, Kep.059/J.A/3/1984 tanggal 13 Maret 1984, dan Kep.-085/J.A/9/1985 tanggal 13 September 1985. 
termasuk dalam kelompok ingkar hadis dikarenakan buku-buku karangan Nazwar Syamsu dianggap memuat sejumlah kutipan ayat-ayat Al-Qur'an yang terjemahan bahasa Indonesia mengandung banyak kesalahan serta pendapat beliau yang dianggap bertentangan dengan keyakinan umat Islam secara umum yang berhubungan dengan sumbersumber ajaran yang dikenal dalam Islam. Hal ini lah yang dijadikan alasan utama dalam mencabut bukubuku karangan Nazwar Syamsu dari peredaran. ${ }^{6}$

Tidak berbedanya dengan Indonesia negara tetangga bahkan serumpun Malaysia pun telah masuk pengaruh-pengaruh dari kelompok ingkar hadis salah satu tokoh yang sangat kontroversial dalam hal ini adalah Kassim Ahmad yang juga dilabeli sebagai ingkar hadis karena salah satu buku karangannya yang berjudul "Hadis Satu Penilaian

6 Howard M. Federspiel, Kajian AlQur'an di Indonesia; dari Mahmud Yunus hingga Quraish Shihab, terj. Tajul Arifin (Bandung: Mizan, 1996), 268.
Semula" pada tahun 1986 yang menggemparkan dan telah menyebabkan beliau dicap menjadi murtad oleh beberapa ulama hingga pelarangan edar oleh kerajaan kelantan

2. Pemikiran Hadis Nazwar

\section{Syamsu dan Kassim Ahmad}

\section{a. Nazwar Syamsu}

Dalam salah satu karya bukunya "Al-Qur'an tentang manusia dan Masyarakat" Nazwar Syamsu secara khusus membahas mengenai sumber hukum dalam Islam, ke dalam dua bab yakni, pada bab pertama tentang "Menghayati Ketentuan Hukum", dan bab kedua tentang "Mematuhi Hukum Allah SWT." dalam uraian bab-bab tersebut Nazwar berpendapat bahwa Al-Qur'an sebenarnya telah cukup sempurna sebagai petunjuk dalam kehidupan sehingga tidak perlu lagi adanya petunjuk maupun sumber hukum yang lain selain Al-Qur'an. 
Bahkan menurut Nazwar bahwa orang yang memasukkan sumber hukum dasar lain selain Al-Qur'an dianggap sebagai kafir, zalim, fasiq dan dianggap syirik. Hal ini menurutnya sesuai dengan firman Allah Swt. Dalam surat al-Maidah ayat 44 , 45 dan $47 .{ }^{7}$

Adapun sebagai sumber hukum kedua dalam pengambilan hukum Islam bagi Nazwar Syamsu, hadis maupun sejarah kehidupan Nabi Muhammad SAW. hanyalah sebagai Uswatun Hasanah, yakni teladan yang baik. Nabi Muhammad SAW. berfungsi sebagai pelaksana hukum yang terkandung dalam Al-Qur'an, Beliau tidak pernah menentang ketentuan Allah SWT. Nabi Muhammad tidak pernah membuat hukum baru karena beliau hanya Rasul yang menyampaikan hukum Allah SWT. juga pengikut ajaran Nabi

7 Nazwar Syamsu, Tauhid dan Logika; al-Qur'an tentang Manusia, Jakarta: PT. Ghalia Indonesia, 1983), 17.
Ibrahim yaitu Islam yang telah sempurna. ${ }^{8}$

Oleh Nazwar Syamsu hadis dalam konteks sekarang ini tidak dapat dipakai sebagai salah satu sumber hukum Islam selain Al-Qur'an hal ini dikarenakan adanya hadis-hadis palsu yang berkembang sebagai pemecah belah kekuatan Islam, hadis-hadis palsu ini muncul dan berkembang hingga tercatat sampai dengan 300.000 bahkan ada yang mengatakan sampai 600.000 buah hadis. Menurutnya hadis palsu ini dibuat oleh para pemecah Islam yang umumnya terdiri Bani Israel beragama Yahudi dan Kristen.

Untuk menerapkan hadishadis palsu yang mengatasnamakan Rasulullah SAW. itu kedalam masyarakat Islam, mereka tidak segan-segan mengeluarkan biaya besar, dengan cara apapun mulai dari

${ }^{8}$ Nazwar Syamsu, Tauhid dan Logika; Al-Qur'an tentang Manusia..., 22. 
membujuk pemuka-pemuka agama yang rapuh iman dengan kekayaan dan sebagainya, bahkan adapula yang pura-pura menjadi penganut Islam dan belajar dengan giat, kemudian mengacau masyarakat Islam dengan berbagai kegiatan. ${ }^{9}$

\section{Posisi Nazwar Syamsu} dalam menyikapi hadis sebagai suatu sumber bimbingan yang tak terbantahkan dan setara dengan Al-Qur'an ialah:

1. Nabi Muhammad selalu berkata dan berbuat sesuai dengan ketentuan hukum dan petunjuk yang terkandung dalam AlQur'an.

2. Muhammad adalah Nabi terakhir dalam daerah Tatasurya kita ini, maka semua ucapan dan perbuatannya adalah Uswah Hasanah (teladan yang baik) bukan hukum. Karena hukum semuanya telah cukup sempurna dalam Al-Qur'an.

3. Hadis Nabi itu belum tentu berasal dari Nabi walaupun hadis tersebut bersesuaian dengan Al-Qur'an dan dapat dipakai, namun hadis bukan dijadikan sebagai dasar hukum.

4. Tugas pokok dari Nabi Muhammad ialah menyampaikan Al-Qur'an sembari membimbing masyarakatnya menurut hukum Al-Qur'an. Banyak hal ilmiah yang diketahui Nabi, tetapi tidak diterangkan beliau mengingat tingkat peradaban yang berlaku, dan sesuai dengan ketentuan Allah, beliau membiarkan pengetahuan manusia kemudiannya berkembang dengan pembukaan yang diizinkan Allah.

${ }^{9}$ Nazwar Syamsu, Tauhid dan Logika; Al-Qur'an tentang Manusia..., 23. 


\section{b. Kassim Ahmad}

Pemikiran Kassim Ahmad tentang Hadis termuat dalam bukunya "Hadis Satu Penilaian Semula" yang awalnya berbahasa Melayu Malaysia dan kemudian di alih bahasakan ke Bahasa Inggris dengan Judul "Hadith a Re-evaluation" yang diberi kata pengantar oleh Hassan Hanafi Professor Filsafat Universitas Kairo Mesir, dan kemudian hari di terjemahkan buku ini kedalam Bahasa Indonesia dengan judul "Hadis di Telanjangi Sebuah Re-evaluasi Mendasar Terhadap Hadis".

Menurut Kassim Ahmad, sunnah ataupun Hadist tetaplah wujud, akan tetapi posisinya tidaklah sama dengan AlQur'an. Ia menolak Hadist/sunnah sebagai sumber teologi dan perundangan sebagai berikut:

1) Al-Qur'an merupakan kitab yang lengkap, sempurna dan terperinci. Ini adalah hukum pokok dan bimbingan dasar untuk umat manusia yang mencakup tiap-tiap aspek kehidupan. Kitab lain hanyalah penjelasan yang sesuai dengannya maupun yang melawan terhadap gagasan agung yang terdapat didalam AlQur'an.

2) Tugas Nabi Muhammad semata-mata hanya menyampaikan Al-Qur'an dan tidak lebih, dan beliau tentu saja juga seorang pemimpin yang patut dicontoh dan seorang guru, tetapi peran ini adalah peran sekunder.

3) Hadis merupakan pandangan manusia yang tidak baik yang tidak terjamin kebenarannya. Maksudnya hadis yang dikompilasikan oleh para ulama hadis terdiri dari riwayat tentang perkataanperkataan dan pelbagai tindakan yang dituduhkan 
dari Nabi dan keasliannya

tidak dapat dijamin dengan

pasti. Hadis-hadis yang sesuai dengan Al-Qur'an bisa diterima, sedangkan yang bertentangan dengannya secara otomatis ditolak.

4) Ibadah-ibadah seperti Shalat, puasa dan lain sebagainya bukan disampaikan oleh hadis melainkan ibadah yang turun-temurun dari Tuhan kepada Nabi Ibrahim dan pengikutnya.

5) Disamping menjadi rasul dan Nabi Tuhan, Muhammad adalah juga seorang pemimpin negarakota Madinah dan kemudian negara-bangsa Arab. Didalam peran itu, Ia menerapkan peraturanperatuaran Ilahi dalam konteks abad ke-7 pada bangsa Arab. Adalah tidak mungkin bahwa ia telah melakukan apapun yang

\author{
bertentangan dengan \\ perintah Tuhan. ${ }^{10}$
}

Menurut

Kassim

penolakannya terhadap hadis sebagai suatu sumber bimbingan yang tak terbantahkan yang setara dengan Al-Qur'an sama sekali bukan berarti penolakan terhadap Nabi Muhammad SAW. Sebaliknya, penolakan ini tepatnya untuk membersihkan nama baik dari ajaran-ajaran palsu yang dihubungkan dengan Nabi Muhammad SAW. yang bertentangan dengan kehendaknya. ${ }^{11}$ Adapun dalam bukunya "Hadis Satu Penilaian Semula" Kassim Ahmad juga menyajikan kritikannya

10 Kassim Ahmad, Hadith Reevaluation, Translated from the Malay Original Monotheism Production Internasional (USA: Tucson Arizona, 1996), 102-103. Lihat juga Kassim Ahmad, Hadis Ditelanjangi; Sebuah Re-evaluasi Mendasar Atas Hadis... 92-93. Atau lihat dalam buku Abdul Choliq Muctar. Hadis nabi dalam teori dan praktek. (Yogyakarta: TH-Prees, 2004), 172.

11 Kassim Ahmad, Hadis Ditelanjangi; Sebuah Re-evaluasi Mendasar Atas Hadis... 92. 
terhadap hadis dari segi sanad dan matan.

3. Persamaan dan perbedaan serta implikasi dari pemikiran Nazwar Syamsu dan Kassim Ahmad

Adapun aspek persamaan serta perbedaan dari pemikiran kedua tokoh ingkar hadis ini yakni:

1). Aspek Persamaan

Otoritas Nabi Muhammad SAW hanya untuk menyampaikan Al-Qur'an.

Bagi Nazwar, Nabi

Muhammad tidak lain hanyalah sebagai penyampai wahyu Tuhan saja. Nabi hanyalah pelaksana hukum yang terkandung didalam AlQur'an. Beberapa ayat-ayat Al-Qur'an yang, menyatakan supaya "mematuhi" dan "mengikuti" Nabi yang dijadikan legitimasi oleh golongan Ahlussunnah terhadap hadis sebagai sumber hukum Islam yang kedua, menurutnya bukanlah dengan mematuhi dan mengikuti Nabi yang sudah meninggal ratusan tahun yang lalu.

Seperti halnya Nazwar Syamsu yang hanya menerima keotoritasan Nabi Muhammad hanya sebagai penyampai wahyu dari Allah saja, Kassim Ahmad pun mempunyai pendapat yang sama mengenai hal ini.

Menurut Kassim hujjahhujjah ahlul Hadis mengandung dua ide dasar: Pertama, Nabi harus dipatuhi tanpa syarat, sama ada sebagai Rasul atau sebagai pemimpin dan hakim. Kedua, kepatuhan kepada Nabi bermakna berpegang kepada Hadis dan Sunnah. Kassim mempertanyakan dua ide ini dengan mengatakan bahwa yang harus diikuti dari Rasulullah hanya 
kerasulannya dan dalam ayat diatas tidak ada katakata Muhammad melainkan menggunakan redaksi “Rasul"12

Sebagai Rasul, Nabi Muhammad adalah perantara yang mengantarkan pesan dan ketaatan kepadanya setara dengan ketaatan kepada Allah. Sebagaimana yang disebutkan dalam Al-Qurán beberapa kali, bahwa tugas Rasul hanyalah untuk menyampaikan pesan. ${ }^{13}$

Menurut penulis, pernyataan Kassim sangat rancu, terutama pada makna kepatuhan kepada Rasul hanya pada kerasulannya saja. Padahal apabila kita lihat ayat berikut:

12 Kassim Ahmad, Hadis Satu Penilaian Semula..., 37.

13 Kassim Ahmad, Hadis Satu Penilaian Semula..., 38 .

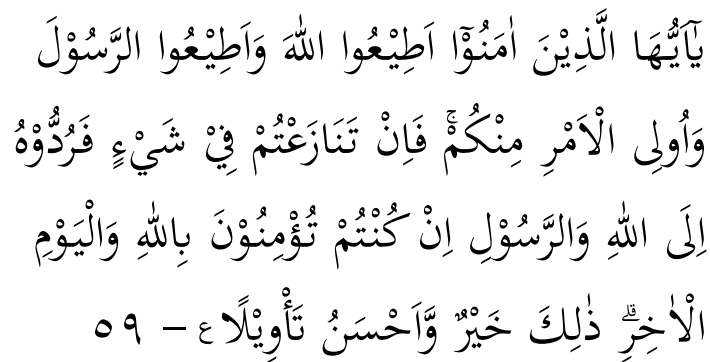

Artinya:

Wahai orang-orang yang beriman! Taatilah Allah dan taatilah Rasul (Muhammad), dan Ulil Amri (pemegang kekuasaan) di antara kamu. Kemudian, jika kamu berbeda pendapat tentang sesuatu, maka kembalikanlah kepada Allah (AlQur'an) dan Rasul (sunnahnya), jika kamu beriman kepada Allah dan hari kemudian. Yang demikian itu lebih utama (bagimu) dan lebih baik akibatnya. (QS. An-Nisa' [4]: 59).

$$
\text { Ayat }
$$

ini

mengindikasikan bahwa apabila kita bertentangan atas sesuatu, maka kita kembalikan pada Allah dan Rasulnya. Pada ayat tersebut siapa dimaksudkan ayat ini kalau bukan Rasulullah SAW. dan apabila terdapat hal hal yang ganjal dalam kepatuhan kita, maka kepada siapa kita bertanya dan berkeluh kesah? AlQur'an menawarkan dua 
opsi: pertama "kembalikan

kepada Allah": yang berarti kembali pada Al-Qur'an sebagai Kalam Allah.

Kedua: "kembalikan kepada Rasulullah". Apa hal ini juga menyuruh hanya menaati kerasulannya saja? Tentu tidak! Karena Muhammad sebagai Rasul memang memiliki kemampuan untuk menyelesaikan masalah dengan bimbingan Allah dan menjadi pemberi kabar baik dan buruk kepada seluruh umat manusia. Tentunya apabila kita menolak hadis dan sunnah (menolak keseluruhannya), darimana kita akan bisa menyelesaikan permasalahan tersebut sesuai makna ayat? Itu karena Rasulullah memang berbicara dan berperilaku berdasarkan bimbingan Allah dibawah naungan Al-Qur'an dan bicaranya Rasul dan berperilakunya Rasul menurut Al-Qur'an itulah yang kita sebut sebagai hadis atau sunnah.

Al-Qur'an adalah satusatunya sumber hukum yang lengkap, sempurna dan terperinci.

Bagi Nazwar Syamsu dan Kassim Ahmad mengenai kedudukan Hadis sebagai sumber hukum kedua setelah AlQur'an, mereka samasama menolaknya, hal ini dikarenakan bagi mereka Al-Quran telah cukup sempurna sebagai petunjuk dalam kehidupan sehingga tidak perlu lagi adanya petunjuk maupun sumber hukum yang lain selain Al-Qur'an.

Oleh

Nazwar dikatakan Hadis Nabi itu belum tentu berasal dari Nabi walaupun hadis tersebut bersesuaian dengan Al-Qur'an dan 
dapat dipakai, namun

hadis bukan dijadikan sebagai dasar hukum. ${ }^{14}$

Bahkan menurutnya bahwa orang yang memasukkan sumber hukum dasar lain selain Al-Qur'an dianggap sebagai kafir, zalim, fasiq, dan dianggap syirik. Hal ini menurutnya sebagaimana firman Allah SWT. dalam surat alMaidah ayat 44,45 , dan 47.15

\begin{tabular}{lr}
\multicolumn{1}{c}{ Sejalan } & dengan \\
pemikiran & Nazwar \\
Syamsu, Kassim & Ahmad \\
juga berargumentasi & \\
bahwa Hadis sebenarnya \\
ada namun posisinya tidak \\
dapat disamakan dengan \\
Al-Qur'an, \\
menolak hadis & sebagai
\end{tabular}

${ }^{14}$ Nazwar Syamsu, Tauhid dan Logika; Al-Qur'an tentang Manusia dan Masyarakat..., 22.

15 Nazwar Syamsu, Tauhid dan Logika; Al-Qur'an tentang Manusia dan Masyarakat..., 17. sumber teologi dan perundang-undangan.

Bagi Kassim Ahmad Al-Qur'an merupakan kitab yang lengkap, sempurna dan terperinci. Ini adalah hukum pokok dan bimbingan dasar untuk umat manusia yang mencakup tiap-tiap aspek kehidupan. Kitab lain hanyalah penjelasan yang sesuai dengannya maupun yang melawan terhadap gagasan agung yang terdapat didalam AlQur'an.

Al-Qur'an dianggap oleh kedua tokoh ini sebagai kitab dan tuntunan hidup yang lengkap,sempurna, dan terperinci. ${ }^{16}$ Disini penulis tidak setuju dengan pemikiran mereka karena keduanya tidak
16 Nazwar Syamsu, Tauhid dan Logika; Al-Qur'an tentang Manusia dan Masyarakat..., hlm. 13, lihat juga, Kassim Ahmad, Hadis Satu Penilaian Semula..., 50. 
menjelaskan apa yang

dimaksud dengan lengkap,

sempurna,

serta

terperincinya Al-Qur'an.

Terlebih lagi Kassim

Ahmad mengatakan

keterperinciannya

Al-

Qur'an dapat dibuktikan

dengan kita mengkaji isi

dari Al-Qur'an itu

sendiri,17 lantas kaifiat dan

metode seperti apa yang

ditawarkan oleh Kassim

supaya keterperincian Al-

Qur'an dapat diketahui?.

Pertentangan ini menurut

penulis berangkat dari

ketidakpahaman Kassim

dan Nazwar terhadap apa

yang dimaksud

pandangan oleh para ahli

hadis bahwa Al-Qur'an

hanya mengandung

ajaran-ajaran pokok saja,

bukan berarti mengatakan

Al-Qur'an tidak lengkap.

17 Kassim Ahmad, Hadis Satu Penilaian Semula..., 51.
Menurut Musthafa alSiba'i sesungguhnya AlQur'an telah memuat pokok-pokok agama (ushulal-din) dan prinsipprinsip hukum umum (qawa'id al-ahkam alammah), disertai nas yang jelas untuk sebagiannya, namun menyerahkan sebagian yang lain kepada Rasulullah SAW. untuk menerangkannya. Dan selama Allah mengutus utusan-Nya untuk menjelaskan kepada ummat manusia apa yang diturunkan kepada mereka berkenaan dengan hukumhukum agama dan mewajibkan mereka menaatinya, maka keterangan apapun yang diberikan Utusan itu adalah keterangan atas AlQur'an. ${ }^{18}$
18 Musthafa al-Siba'i, , "al-Sunnah wa Makanatuha fi al-Tasyri'al-Islami" diterjemahkan oleh Nurchalis Madjid dengan judul Sunnah dan Peranannya dalam Penetapan 
Dari sini berarti

hukum-hukum agama, baik yang dari kitab maupun Hadis serta Ijma' dan qiyas yang terkait padanya dan menjadi pencabangannya adalah sebenarnya hukum-hukum yang langsung berasal dari kitab Allah SWT. Jadi tidak ada pertentangan antara kedudukan Hadis sebagai sumber hujjah dengan kedudukan Al-Qur'an yang turun sebagai keterangan atas segala perkara.

Hadis Nabi tidak dapat dipercaya.

Dalam pandangan Nazwar Syamsu hadis dalam konteks sekarang ini tidak dapat dipakai sebagai salah satu sumber hukum Islam selain AlQur'an hal ini dikarenakan adanya hadis-hadis palsu

Hukum Islam, (Jakarta: Pustaka Firdaus, 1993), 125. yang berkembang sebagai

pemecah belah kekuatan Islam, hadis-hadis palsu ini muncul dan berkembang hingga tercatat sampai dengan 300.000 bahkan ada yang mengatakan sampai 600.000 buah hadis. Menurutnya hadis palsu ini dibuat oleh para pemecah Islam yang umumnya terdiri Bani Israil beragama Yahudi dan Kristen.

Adapun keraguan Nazwar terhadap Hadis Nabi yaitu para periwayat/penyusun dari hadis-hadis Nabi hidup setelah 200 tahun Nabi Muhammad meninggal dunia, yang mana pada masa itu Bani Israil dengan sengaja membuat hadishadis palsu yang diperuntukkan untuk meruntuhkan kesempurnaan Islam yang 
hanya berdasarkan Al-

Qur'an dan memang

ketika itu terjadi pula perpecahan bangsa Arab.

Seperti halnya Nazwar yang menganggap hadis merupakan sebuah kebohongan yang mangatasnamakan Nabi SAW. semata, Kassim Ahmad juga memandang hadis sebagai pandangan dan pendapat manusia yang tidak terjamin kebenarannya, hadis sendiri tidak lebih hanya sebuah perkiraan terhadap apa yang telah dilakukan dan diucapkan Nabi.

$$
\text { Kassim }
$$

Ahmad

berpendapat, umat Islam telah menyimpang dari ajaran Tuhan yang telah dibawa oleh Rasulullah SAW. yaitu Al-Qur'an tidak yang lain daripada Al-Qur'an. Menurutnya hadis merupakan suatu ajaran palsu yang muncul antara 200-250 tahun yang dihubungkan dengan Nabi Muhammad. Ini merupakan salah satu alasan perpecahan dan kemunduran umat Islam. ${ }^{19}$ banyak hadis yang bertentangan dengan AlQur'an, adanya hadis bukan dari kehendak Nabi, melainkan lahir karena faktor politik dan dalam rangka mendukung kepentingan individual atau kelompok ${ }^{20}$ sehingga timbul pemalsuan hadis. ${ }^{21}$

${ }^{19}$ Kassim Ahmad, Hadis Satu Penilaian Semula..., 18.

20 Kassim Ahmad, Hadis Satu Penilaian Semula..., 17.

21 Masalah pemalsuan hadis Kassim Ahmad mengutip alasan-alasan pemalsuan hadis dari bukunya Ahmad Amin (Fajr alIslam), didalam buku ini disebutkan ada lima sebab terjadinya pemalsuan hadis, yaitu: 1) karena adanya pergolakan politik antar sesama umat Islam. 2) perselisihan pendapat para ulama dalam bidang-bidang Ilmu kalam, Fiqh,. 3) Kecondongan sementara para ulama terhadap keinginan penguasa pada waktu itu. 4) karena adanya ulama yang membolehkan mengarang suatu hadis yang menganjurkan kebaikan dan ibadah serta larangan berbuat maksiat (hadis ini bertujuan untuk menggalakkan kebaikan dan mencegah kemungkaran). 5) adanya sifat 
Jika dilihat dari pemikiran-pemikiran dari Nazwar dan Kassim diatas menurut Syuhudi Ismail bahwa alasan yang dibuat oleh seseorang yang sangat awam pengetahuannya dibidang Hadis dan sejarah penulisan Hadis.

Hal ini karena pada zaman Nabi SAW. cukup banyak Hadis Nabi yang secara resmi ditulis. Dikatakan resmi karena Nabi sendiri yang menyuruh sahabat tertentu untuk menulisnya. Sebagian dari hadis yang secara resmi dicatat pada zaman Nabi itu adalah surat-surat Nabi ke berbagai kepala pemerintahan dan negara. Disamping itu,

orang yang berlebih-lebihan ketika itu yang tidak mau menerima ilmu kecuali yang bersumber dari Al-Qurán dan hadis, seperti adanya nasihat-nasihat bijak yang sebenarnya datang dari negeri India, Yunani dll. (adanya ajaran-ajaran baik dari sumbersumber bukan Islam). Untuk lebih jelasnya lihat dalam buku Kassim Ahmad, Hadis Satu Penilaian Semula..., 67. kalangan sahabat Nabi juga cukup banyak yang atas inisiatif sendiri melakukan kegiatan penulisan hadis. Sebagian dari mereka itu ialah 'Ali bin Abi Thalib, 'Abdullah bin 'Abbas, dan 'Abdullah bin Amr bin 'Ash. Kegiatan penulisan itu berjalan terus dimulai dari zaman Nabi sampai dengan masa penghimpunan hadis secara resmi. ${ }^{22}$

2). Aspek Perbedaan

Setidaknya ada hal yang mendasar yang mempengaruhi pemikiran Hadis Nazwar Syamsu dilihat dari karyakaryanya yang lebih konsen dalam menafsirkan ayat-ayat Al-Qur'an dibandingkan dengan Hadis, hal ini menurutnya karena Al-Qur'an sebenarnya telah cukup sempurna bagi petunjuk hidup, sehingga tidak perlu adanya petunjuk ataupun sumber

22 Syuhudi Ismail, Hadis Nabi Menurut Pembela, Pengingkar, dan Pemalsunya. (Jakarta: Gema Insani Press, 1995), 31-32. 
hukum yang lain selain AlQur'an.

Ketertarikan

Nazwar

Syamsu terhadap Al-Qur'an

berawal pada saat beliau

memulai debut dakwah di zaman perang gerilya PRRI. Jika dilihat dari beberapa karyakarya Nazwar Syamsu tertarik dalam menganalisis pendapat para ilmuan Barat $^{23}$ dan mengemukakan kekeliruankekeliruan yang mereka perbuat dengan menggunakan sumbersumber ajaran agama. Serta beberapa artikel dan buku yang menyangkut tentang Hadis ditulis oleh para pemikir Indonesia juga sedikit membuat Nazwar ragu akan Hadis. ${ }^{24}$

23 Adapun Orientalis yang turut mempengaruhi pemikiran Nazwar tentang hadis adalah H.A.R. Gibs dan J.H Krames. Lihat Nazwar Syamsu, Al-Qur'an tentang Manusia dan Masyarakat..., 30.

24 Beberapa artikel dan buku yang disebutkan oleh Nazwar sebagai argumentasi penolakan hadis didalam bukunya antara lain: artikel dalam Panji Masyarakat No. 64 September 1970 oleh Eva Sa' adah dengan judul "Peranan Hadis-Hadis Palsu dalam Menghancurkan Dunia Islam"; buku "Ilmu Mushthalah Hadis" karya dari
Adapun dalam karyanya Nazwar sangat bersandar pada Al-Qur'an, Bibel berbahasa Inggris, dan beberapa Ensiklopedi Standar dalam berbahasa Inggris. Dalam bukubukunya tidak terdapat sumber berbahasa Arab bahkan hanya beberapa penulis Arab terkenal yang disebutkan olehnya, didalam keseluruhan isi bukubuku tersebut terdapat ribuan ayat suci Al-Qur'an yang dikutip dalam Bahasa Arab dan terjemahan Bahasa Indonesia. ${ }^{25}$

Di dalam pendahuluan setiap buku yang ia tulis, Nazwar senantiasa menghindari pernyataan secara langsung tentang posisinya yang menolak hadis sebagai sumber ajaran. Adapun dalam karya-karyanya

Mawardi Muhammad yang diterbitkan oleh Pustaka Sa'adiyah Bukit Tinggi Sumatera Barat; buku "Ikhtiar Musthalah al-Hadits" karya dari Drs. Fatchur Rahman yang diterbitkan oleh PT. Al-Ma'arif Bandung Jawa Barat. Lihat, Nazwar Syamsu, al-Qur'an tentang Manusia dan Masyarakat..., 24-29.

25 Howard M. Federspiel, Kajian AlQur'an..., 262-263. 
Nazwar selalu berpegang kepada Al-Qur'an saja sementara dalam menerjemahkan dan menafsirkan ayat-ayat di dalam Al-Qur'an Nazwar hanya menerjemahkan sesuai dengan akal pikirannya sendiri sama sekali tidak mau menengok hadis, dan juga Nazwar tidak mau menggunakan terjemahan orang lain walaupun menurut Harun Al-Ma'any penguasaan Bahasa Arab Nazwar Syamsu “agak lemah". ${ }^{26}$

Adapun Kassim Ahmad memiliki latarbelakang pemikiran yang berbeda dari Nazwar Syamsu, keterpengaruhan pemikiran keIslaman dari Kassim Ahmad berawal ketika berada di Eropa (London), yaitu keluasan vitalitas dan aktivitas kehidupan orang Eropa; inisiatif orang-orang di eropa yang dilihatnya, jika tidak setuju

${ }^{26} \mathrm{NN}$, “Ingkar Sunnah atau Ingkar Apa?" dalam Tempo, 24 Maret 1984, 64. terhadap suatu hal mereka akan mengubahnya.

Yang menjadi latar belakang pemikiran Kassim Ahmad untuk merubah kedudukan dan fungsi hadis dan sunnah terhadap Al-Qur'an, Kassim banyak merujuk, dan terpengaruh oleh pemikirpemikir yang selama ini dikenal sebagai anti hadis oleh kalangan tertentu, seperti Dr. Rasyad Khalifa seorang pengingkar sunnah warga negara Amerika berasal dari Mesir dengan bukunya berjudul Nothing but Qur'an dan The Computer Speaks: God's Message to the world pada awal tahun 1985. demikian juga dengan Ahmad Amin yang prinsip penolakan terhadap hadis, dalam karyanya "Fajr alIslam" juga memberikan sumbangsih bagi pemikiran Kassim Ahmad. Banyak dari statemen Ahmad Amin yang dijadikan Kassim sebagai referensi utama khususnya dalam kajian kritik hadis. 
Selain dari tokoh-tokoh yang telah disebutkan Nazwar Syamsu juga memberikan kontribusi bagi pemikiran Kassim Ahmad hal ini tidak dapat dipungkiri walaupun secara eksplisit Kassim tidak mengakui hal itu sebagaimana dengan Rasyad Khalifa. ${ }^{27}$

3). Implikasi Pemikiran Hadis Nazwar Syamsu dan Kassim Ahmad

Pemikiran Nazwar Syamsu dan Kassim Ahmad yang berbeda dengan ajaran Islam mayoritas baik di Indonesia dan Malaysia telah menimbulkan berbagai dampak sosial dalam masyarakat, terutama pada masyarakat Islam, antara lain:

a) Terjadinya disorganisasi diberbagai kelompok jamaah Islam, yang kemudian menimbulkan kelompok jamaah Islam yang baru, yakni Jamaah

27 Hal ini dapat dilihat dari beberapa point persamaan pemikiran dari kedua tokoh ini yang penulis jelaskan pada kajian sebelumnya.
Islam Qur'ani (Jama'ah Qur'aniyyun) di Indonesia pada tahun 1978 di Indonesia Nazwar Syamsu pernah menjadi pimpinan Jama'ah ini dan Kassim Ahmad dengan Jama'ah AlQur'an Malaysia (JAM) yang dibentuk olehnya pada tahun 1995 namun sebelumnya Kassim Ahmad pernah menggagas sebuah Majlis Diskusi yang membahas "Teori Hadis" di kantor ALIRAN (Aliran Kesadaran Rakyat) pada september 1985 di Malaysia.

b) Timbulnya sanggahan dari berbagai pihak terhadap ajaran-ajaran dari Nazwar Syamsu dan Kassim Ahmad, yang berbentuk tulisan baik yang berbentuk buku maupun yang berbentuk majalah, maupun berita harian.

c) Timbulnya keprihatinan para ulama terhadap pengembangan pemikiran 
dari Nazwar dan Kassim

yang dapat merusak dasar

Agama Islam, di Indonesia

Ulama Indonesia (MUI)

dan keputusan mengenai

kelompok jama'ah yang

tidak mempercayai hadis

Nabi Muhammad SAW.

syari'at Islam, adalah sesat

dan menyesatkan dan

berada diluar agama Islam.

d) Timbulnya kewaspada-an

pemerintah Indonesia dan

pihak kerajaan Malaysia

dalam rangka memelihara

kestabilan Nasional

sehingga pemerintah

Indonesia dan Malaysia

mengeluarkan larangan

terhadap pengembangan

ajaran yang dianggap

menyimpang dari ajaran

Islam mayoritas. hal ini datang dari Majelis

yang mengeluarkan fatwa

sebagai sumber hukum

Negara Indonesia Jaksa

Agung mengeluarkan

kembali Surat Keputusan

No. KEP-059/J.A./3/1984

tentang larangan peredaran kaset suara Nazwar Syamsu yang memuat ajaran dari kelompok penolak hadis. Kemudian disusul dengan Surat Keputusan Jaksa Agung RI No. KEP085/J.A/9/1985 tentang larangan peredaran barangbarang cetakan dan rekaman suara dari Nazwar Syamsu.

Sedangkan di Malaysia karya-karya dari Kassim Ahmad pun memiliki nasib yang sama dengan Nazwar Syamsu yakni pemerintah dalam hal ini kerajaan Malaysia melarang buku "Hadis Satu Penilaian semula" melalui Warta Kerajaan tertanggal $10 \mathrm{Juli}$

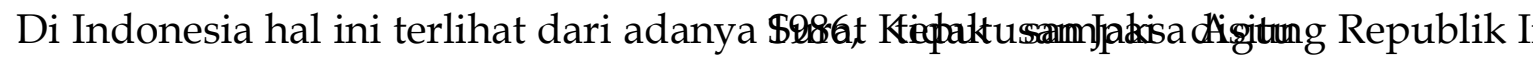
Hadis di Indonesia. Demi saja pada Oktober 1992 menjaga kestabilan dalam

Kassim dengan


pendiriannya yang sama, menulis buku lagi yang berjudul "Hadis Jawapan Kepada Pengkritik" pemerintah sekali lagi melarang buku tersebut melalui Warta Kerajaan tertanggal 21 April 1994. Hingga sekarang kelompok yang didirikan Oleh Kassim Ahmad “Jama'ah Al-Qur'an Malaysia" tidak diberi izin oleh pihak Kerajaan Malaysia karena ajaranajarannya yang menyimpang dari ajaranajaran Islam yang ada.

\section{SIMPULAN}

Ingkar Sunnah di Indonesia telah muncul sekitar tahun 1978 secara diam-diam dan diketahui oleh masyarakat muslim Indonesia pada tahun 1980-an hingga memunculkan berbagai keresahan bagi masyarakat khususnya di Ibukota Jakarta hingga akhirnya pada tahun 1983 pemerintah RI mengeluarkan SK Jaksa Agung tentang pelarangan ajaran Ingkar Sunnah dengan No. Kep-169/J.A/9/1983 yang sebelumnya juga di fatwakan oleh MUI bahwa Ingkar Sunnah sebagai aliran sesat pada tanggal 27 Juni 1983, Sedangkan di Malaysia Ingkar Sunnah baru mulai berkembang pada tahun 1985 kelompok Anti hadis ini dipelopori oleh Kassim Ahmad yang terpengaruh oleh ajaran Dr. Rashad Khalifa, mereka mencoba menarik perhatian umat Islam dengan mengemukakan teori bahwa ajaran Islam telah lengkap dengan hanya berdasarkan Al-Qur'an semata, pemikiran yang berbeda inilah yang membuat keresahan dalam masyarakat baik di Indonesia dan Malaysia.

Nazwar Syamsu merupakan seorang pemikir muslim yang enggan terhadap penggunaan hadis-hadis Nabi, semua pemikirannya dan hujjahnya menggunakan ayat-ayat Al-Qur'an dan Ilmu pengetahuan modern. Baginya Hadis maupun sejarah kehidupan Nabi Muhammad SAW. hanyalah sebagai Uswatun Hasanah. Nabi tidak mempunyai 
wewenang dalam menetapkan hukum baru selain yang ada di dalam Al-Qur'an karena tugas dari Nabi hanya menyampaikan hukum Allah SWT. yang juga pengikut dari ajaran Nabi Ibrahim yaitu Islam. Oleh Nazwar Hadis dalam konteks sekarang ini tidak dapat digunakan sebagai salah satu sumber hukum Islam selain Al-Qur'an hal ini karena Hadis Nabi baginya belum tentu berasal dari Nabi (adanya hadishadis palsu) walaupun hadis tersebut tidak bertentangan dengan Al-Qur'an dan dapat digunakan. Tetapi hadis tidak dapat dijadikan sebagai dasar hukum.

Hal senada juga dipaparkan oleh Kassim Ahmad menurutnya hadis merupakan salah satu faktor kemunduran umat Islam hal ini disebabkan keotentikan hadis yang tidak bisa dipercaya bersumber dari Nabi Muhammad SAW. Pada karyanya Hadis Satu Penilaian Semula kassim terlihat tidak konsisten pada jalan pemikirannya, yakni pada satu sisi Kassim menolak hadis secara mutlak, sedangkan sisi lain beliau juga menerima hadis yang selaras dengan Al-Qur'an pada batas-batas tertentu.

Hal ini menunjukkan bahwa baik Nazwar Syamsu maupun Kassim Ahmad tidaklah menolak hadis secara menyeluruh, tetapi hanya Ingkar Hadis sebagian saja. Walaupun pemikiran keduanya banyak dipengaruhi oleh para orientalis dan para pengingkar sunnah, namun sebenarnya apa yang mereka lakukan bisa dikatakan sebagai wujud kecintaannya kepada Islam, juga kepada Rasulullah SAW.

Adapun hasil dari pemikiran dari Nazwar Syamsu dan Kassim Ahmad tentang Hadis juga telah memberikan implikasi yang besar dalam dunia Islam baik pada Aqidah dan syari'at Umat Islam, maupun juga sosial masyarakat di masingmasing negara mereka mengembangkan ajarannya. Hal ini terlihat di Indonesia adanya berbagai keresahan dan kecaman dari berbagai pihak untuk melarang ajaran yang diajarkan oleh Nazwar baik berupa buku-buku karangannya yakni 
"Tauhid dan Logika" (terdiri dari 9 seri buku) maupun kaset-kaset rekaman ceramahnya (terdiri dari 23 judul kaset) mendapat larangan peredaran dari Jaksa Agung RI karena isinya memutar yang balikkan kebenaran Al-Qur'an dapat meresahkan masyarakat Indonesia. Sama halnya dengan Nazwar, Kassim Ahmad pun tidak luput dari berbagai kecaman dari berbagai pihak di Malaysia, baik itu dari para Ulama dan tokoh-tokoh keagamaan, maupun dari pihak Kerajaan Malaysia yang melarang peredaran buku-buku karangan Kassim yang dianggap menyesatkan umat. 


\section{DAFTAR PUSTAKA}

Abdullah, Abdurrahman Haji, Pemikiran Islam di Malaysia: Sejarah dan Aliran, Jakarta: Gema Insani, 1997.

Ahmad, Kassim, Hadith Re-evaluation, Translated from the Malay Original Monotheism Production Internasional. USA: Tucson Arizona, 1996

Hadis Ditelanjangi; sebuah Re-evaluasi Mendasar Atas Hadis, terj. Asyrof Syarifuddin, Yogyakarta: Trotoar, 2006 Hadis Jawapan Kepada Pengkritik, Kuala Lumpur: Media Indah Sdn Bhd, 1992

Al-Siba'i, Musthafa, "al-Sunnah wa Makanatuha fi al-Tasyri'al-Islami" terj. Nurchalis Madjid. Jakarta: Pustaka Firdaus, 1993

Anwar, Zainal, Kebangkitan Islam di Malaysia, Alih bahasa Umm Hasannain, Jakarta: LP3ES, 1990

Departemen Agama RI, Al-Qur'an dan Terjemahnya, Jakarta: Proyek Pengadaan Kitab Suci AlQur'an, 1971.

Harun Nasution, Islam Ditinjau dari Berbagai Aspeknya, jilid I, Cet V. Jakarta: UI Press, 1989

Husnan, Ahmad, Gerakan Ingkar AlSunnah dan Jawabannya, Jakarta: Media Da' wan, 1984
Ismail, Syuhudi, Hadis Nabi Menurut Pembela, Pengingkar, dan Pemalsunya. Jakarta: Gema Insani Press, 1995

Jaiz, Hartono Ahmad, Aliran dan Paham Sesat di Indonesia, Jakarta: Pustaka Al-Kautsar. 2012

Khon, Abdul Majid, Pemikiran Modern dalam Sunnah, Jakarta: Kencana, 2011

Majelis Ulama Indonesia (MUI) tanggal 27 Juni 1983 tentang Kesesatan Ingkar Sunnah, Himpunan Fatwa MUI, Jakarta: MUI, 2003

M. Federspiel, Howard, Kajian AlQur'an di Indonesia; dari Mahmud Yunus hingga Quraish Shihab, terj. Tajul Arifin. Bandung: Mizan, 1996

NN, "Ingkar Sunnah atau Ingkar Apa?" dalam Tempo, 24 Maret 1984

Syamsu, Nazwar, Tauhid dan Logika; al-Qur'an tentang Manusia, Jakarta: PT. Ghalia Indonesia, 1983

Tauhid dan Logika; serial Al-Qur'an tentang Makkah dan Ibadah Haji. Jakarta: PT. Ghalia Indonesia, 1983 